\title{
Synthesis, Biological Evaluation, and Docking Analysis of Methyl Hydroquinone and Bromo Methyl Hydroquinone as Potent Cyclooxygenase (COX-1 and COX-2) Inhibitors
}

\author{
Nursamsiar ${ }^{1, *}$, Aiyi Asnawi², Rahmana E. Kartasasmita², Slamet Ibrahim², Daryono Hadi Tjahjono \\ ${ }^{1}$ Department of Pharmaceutical Analysis, Sekolah Tinggi Ilmu Farmasi Makassar, Makassar, South Sulawesi, 90242, Indonesia. \\ ${ }^{2}$ School of Pharmacy, Bandung Institute of Technology, Bandung, West Java, 40132, Indonesia.
}

\section{ARTICLE INFO \\ Article history: \\ Received on: 10/05/2018 \\ Accepted on: 25/06/2018 \\ Available online: 30/07/2018}

\section{Key words:}

Bromination,

Cyclooxygenase,

Hydroquinone,

Inflammation, NSAIDs.

\begin{tabular}{l}
\hline ABSTRACT \\
NSAIDs reduce inflammation and relieve fever and pain by blocking enzymes and proteins but may cause side effects \\
and complications by their use. It is therefore important for any molecular modification to enhance their pharmacological \\
properties. In the present investigation, synthesis, biological evaluation, and molecular docking were performed for \\
both methyl hydroquinone (1) and its brominated compound (2) to evaluate their anti-inflammatory activity against \\
cyclooxygenase protein as a model compound and the data compared with its native ligands. Bromination of methyl \\
hydroquinone using dichloromethane as solvent gave the highest yield. In vitro COX-1/COX-2 inhibition studies \\
showed that compound $\mathbf{2}$ was a more potent COX inhibitor than compound $\mathbf{1}$. The brominated compound (2) showed \\
lower binding energy and RMSD values compared to methyl hydroquinone. Analysis of protein and ligand binding \\
revealed that both $\mathbf{1}$ and $\mathbf{2}$ fitted into the active site and interacted with protein amino acid residues Tyr385 and Met522 \\
in COX-1 and Tyr385, Ser530, Val523, Ala527, and Leu384 in COX-2. Substitution of bromine plays an important \\
role in the anti-inflammatory activity of methyl hydroquinone.
\end{tabular}

\section{INTRODUCTION}

NSAIDs work by reducing the production of prostaglandins. Prostaglandins are chemicals which not only promote inflammation, pain, and fever but also protect the lining of the stomach and intestines from the damaging effects of acid, promote blood clotting by activating blood platelets, and promote normal function of the kidneys (Buer, 2014). Most NSAIDs (e.g. aspirin) inhibit the activity of cyclooxygenase-1 (COX-1) and cyclooxygenase-2 (COX-2). Inhibiting COX-1 may cause gastrointestinal bleeding and ulcers and those NSAIDs that also inhibit COX-2 have anti-inflammatory, analgesic, and antipyretic effects (Page et al., 1998).

NSAIDs may cause serious cardiovascular side effects and complications (Wolfe et al., 1999). Therefore, the challenge

\footnotetext{
"Corresponding Author

Nursamsiar, Department of Pharmaceutical Analysis, Sekolah Tinggi

Ilmu Farmasi Makassar, Makassar, South Sulawesi, Indonesia.

E-mail:n.siar@yahoo.co.id
}

still exists for the pharmaceutical industry to develop an NSAID with fewer side effects. It is therefore important for any molecular modification to enhance its pharmacological properties by predicting molecular interaction with its ligand (Nursamsiar et al., 2013) and protein/enzyme as well as chemical reactions.

Methyl dihydroquinone is a group of aromatic compounds containing a methyl group, two opposite hydroxyl groups $(-\mathrm{OH})$, and two other pairs of carbon atoms linked by a vinylene group $(-\mathrm{CH}=\mathrm{CH})$ in a six-membered unsaturated ring (Scheme 1). The considerable biological importance of methyl hydroquinone in inhibiting the growth of endothelial and tumor cells in culture in the micromolar range makes it a promising drug candidate in the treatment of cancer and other angiogenesis-related pathologies (García-Caballero et al., 2013). Besides that, studies have described simple chemical modification by bromination of methyl hydroquinone representing anti-inflammatory activity as well as an intermediate in our next step in researching the synthesis of curculigoside.

Promoted by the above-mentioned studies and as part of our research interest in the synthesis and biological activity of 
curculigoside, the present study is concerned with the bromination of methyl hydroquinone in various solvents with the objective of discovering potent anti-inflammatory agents. Bromomethyl hydroquinone and methyl hydroquinone were tested for their inhibitory activity against COX-2 and COX-1 enzymes and their binding mode to the enzymes was predicted using docking studies.

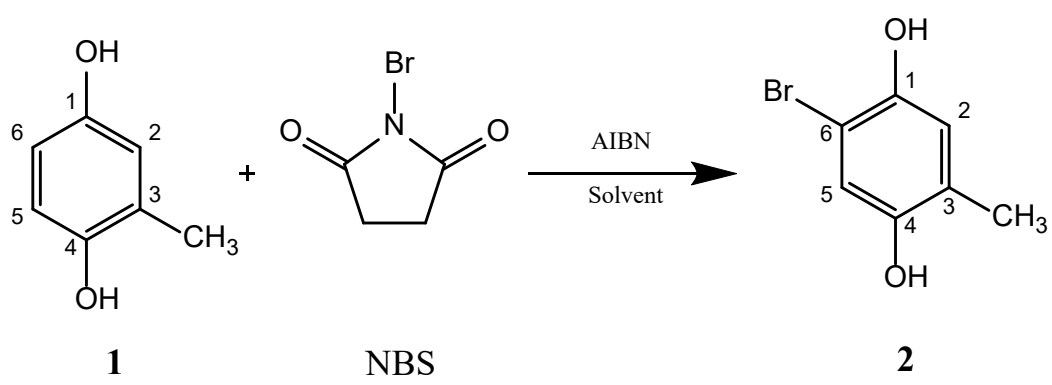

Scheme 1: Bromination of methyl hydroquinone (1) using N-bromosuccinimide (NBS) and azobisisobutyronitrile (AIBN) in various solvents.

\section{MATERIAL AND METHODS}

\section{Chemistry and synthesis}

The procedure had some modification from Djerassi (1948): a solution of methyl hydroquinone (1) $(0.1 \mathrm{~mol})$ in solvent was heated to reflux after which NBS $(0.12 \mathrm{~mol})$ and AIBN were carefully added in a portion-wise manner over $5 \mathrm{~min}$. After completion of the addition, three portions of AIBN were added. After $3 \mathrm{~h}$ the mixture was cooled to room temperature and the solvent was removed to yield a brown solid. A further purification by recrystallization from chloroform was carried out.

\section{Cyclooxygenase inhibitory assay}

The effect of the compounds on ovine COX-1 and human recombinant COX-2 (IC50 value, mM) enzymes were determined by measuring prostaglandin F2a (PGF2a) using a COX Inhibitor Screening Kit (Catalog No 560131) from Cayman Chemical, Ann Arbor, Michigan, USA, following the procedure suggested by the manufacturer. The IC50 values (the concentration of the test compound causing 50\% inhibition) were calculated from the concentration inhibition response curves (duplicate determinations).

\section{Docking studies}

MGLTools 1.5.4 software (Molecular Graphics Laboratory, The Scripps Research Institute) was used for preparation of protein and ligand structure, file parameter grids, and file parameter docking, the Autogrid v4.2 program package (The Scripps Research Institute) was used in preparation of grids, and the AutoDock v4.2 program package (http://autodock.scripps. edu) was used in processing the docking simulation via the Cygwin program (www.cygwim.com). Docking to macromolecules was performed using an empirical free energy function and Lamarckian genetic algorithm, with an initial population of 2,500,000 energy evaluations, a mutation rate of 0.02 , and a crossover rate of 0.80 . Here, 100 independent docking runs were performed for each ligand. After the simulation was completed, analysis of docking results was done, which covered interaction of ligand-receptor parameters including hydrogen bond, free energy of bonding $(\Delta G)$, inhibition constant, and amino acid residues on bonding site receptors. Visualization of docking results was carried out using the Discovery Studio 3.5 Visualizer package.

\section{RESULTS AND DISCUSSION}

\section{Synthesis of bromomethyl dihydroquinone (2)}

Bromination of methyl dihydroquinone (1) occurs at the carbon atom of the vinylene group by electrophilic substitution of a bromine radical. The reaction was carried out using NBS (N-bromosuccinimide) as a brominating agent (Huafe et al., 2004) and AIBN (azobisisobutyronitrile) as a radical initiator (March, 1985) in various solvents. The bromination of $\mathbf{1}$ was greatly affected by solvent. We examined the bromination of 1 in various solvents. Bromomethyl dihydroquinone (2) was prepared in good yield $(79.2 \%)$ in chloroform. When synthesis was carried out in other solvents, the yield was decreased. The yield of product in dichloromethane, ethyl acetate, and $n$-hexane was $51.7 \%, 50.4 \%$, and $32 \%$, respectively. NBS can be a convenient source of $\mathrm{Br}$. (bromine radical) and chloroform was the best solvent for those reactions. The reaction product was confirmed by NMR and mass spectroscopy (Figure 1).

The ${ }^{1} \mathrm{H}-\mathrm{NMR}$ spectra of $\mathbf{2}$ showed the disappearance of the proton signals (doublet) at about $6.6 \mathrm{ppm}$, indicating the electrophilic substitution of the bromine radical to the vinylene group in para position during the reaction. Aromatic compounds such as phenol and aniline and heterocyclic aromatic (Amat et al., 1998) can be brominated using NBS (Gilow and Burton, 1981) to yield a bromo para-selectivity product (Mitchell et al., 1979). Bromine substitution at atom C-6 caused a chemical shift in the position of $\mathrm{C}-5$ atom downfield as well as splitting the proton signal for C-5, altering it from a doublet to a singlet (Table 1).

Mass spectrometry-electrospray ionization (MS-ESI) was applied to determine the molecular weight of the brominated product. The mass spectrum showed a persistent peak at a mass of 200.957 (Figure 2). This $m / z(\mathrm{M}+1)$ was identical to the molecular weight of 2 (203.9586). This result confirmed that the product contained 2 .

\section{Cyclooxygenase inhibitory activity}

Compounds $\mathbf{1}$ and $\mathbf{2}$ were evaluated for their ability to inhibit COX-1 and COX-2 enzymatic activity using a COX Inhibitor Screening Assay Kit. The potency $\left(\mathrm{IC}_{50}\right.$ values) of test compounds was determined; their $\mathrm{IC}_{50}$ values and selectivity indices (SI) are given in Table 2. In vitro COX-1/COX-2 inhibition studies showed that compound $\mathbf{2}$ was a more potent 
COX inhibitor than compound 1 (SI $\sim 1$ ). High activity of the anti-inflammatory activity.

bromine substituent plays an important role in dihydroquinone
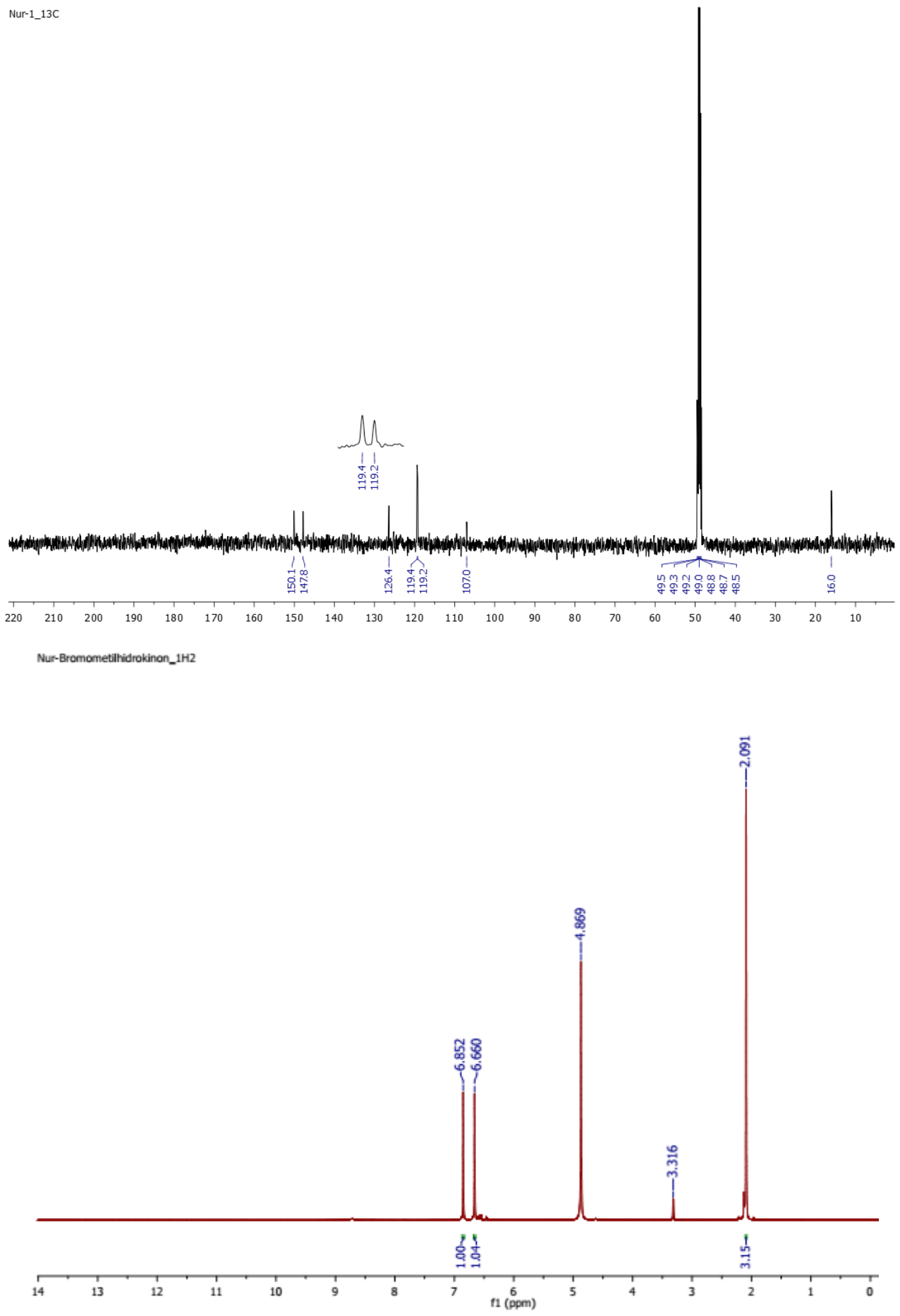

Fig. 1: ${ }^{1} \mathrm{H}$ - and ${ }^{13} \mathrm{C}$-NMR spectra of bromomethyl dihydroquinone (2) (in $\mathrm{CD}_{3} \mathrm{OD}$ ).

\section{Docking studies}

Molecular docking is used to understand and predict molecular recognition, find likely binding modes, and predict binding affinity (Morris et al., 2008). Study of the interaction between compounds $\mathbf{1}$ and $\mathbf{2}$ and protein was done to find the properties of active sites, binding energies, etc. In this study, AutoDock 4.2 (Morris et al., 2009) software was used as an engine to conduct the molecular docking with validation of results based on an RMSD value $=2.0$ (Trott and Olson, 2010). The crystal structure of cyclooxygenase-1 in complex with flurbiprofen 
(PDB code: $3 \mathrm{~N} 8 \mathrm{Z}$ ) as $\mathrm{COX}-1$ protein and the crystal structure of cyclooxygenase-2 complexed with a selective inhibitor (PDB

code: $6 \mathrm{COX}$ ) as COX-2 were used as protein (macromolecule).

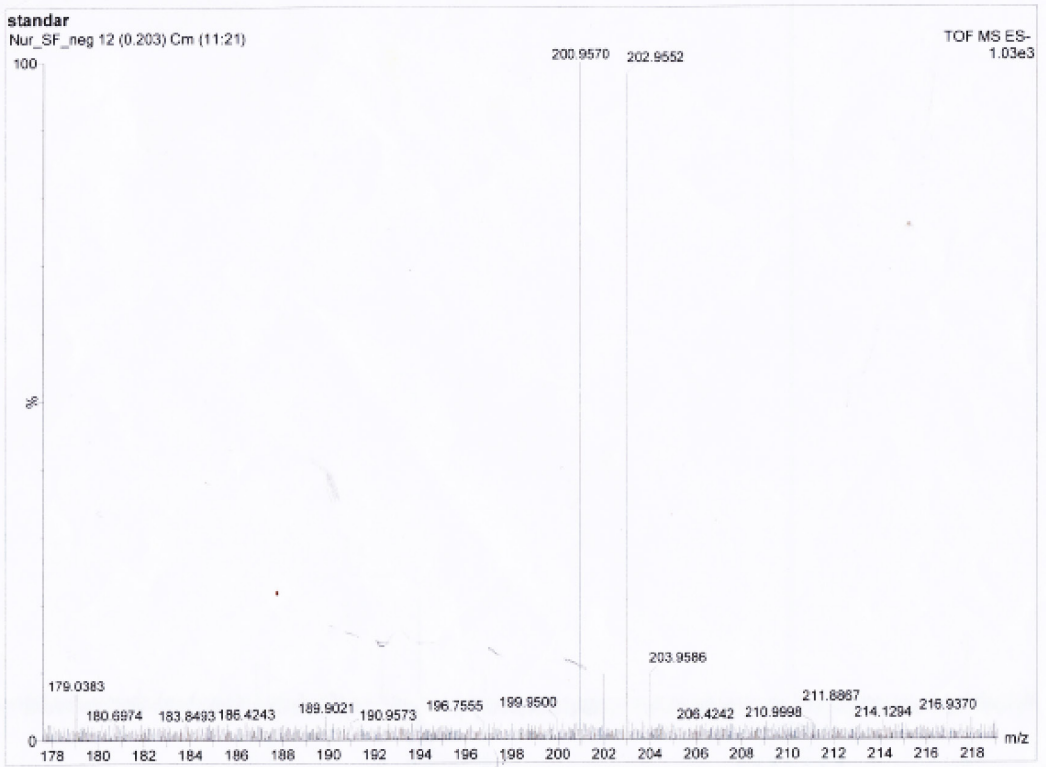

Fig. 2: Mass spectrum of bromomethyl dihydroquinone (2).

Table 1: Chemical shifts of proton and carbon resonances of bromomethyl dihydroquinone (2).

\begin{tabular}{cccc}
\hline Proton $^{\mathbf{a}}$ & ${ }^{1} \mathbf{H}-\mathbf{N M R}$ & Carbon $^{\mathbf{b}}$ & ${ }^{13} \mathbf{C}-\mathbf{N M R}$ \\
\hline $\mathrm{CH}_{3}$ & $2.091(\mathrm{~s}, 3 \mathrm{H})$ & $\mathrm{CH}_{3}$ & 16.0 \\
$\mathrm{OH}$ & $4.869(\mathrm{~s}, 2 \mathrm{H})$ & $\mathrm{C}-6$ & 107.0 \\
$\mathrm{H}-2$ & $6.660(\mathrm{~s}, 1 \mathrm{H})$ & $\mathrm{C}-2$ & 119.2 \\
$\mathrm{H}-5$ & $6.852(\mathrm{~s}, 1 \mathrm{H})$ & $\mathrm{C}-5$ & 119.4 \\
& & $\mathrm{C}-3$ & 126.4 \\
& & $\mathrm{C}-1$ & 147.8 \\
& & $\mathrm{C}-4$ & 150.1 \\
\hline
\end{tabular}

${ }^{1} \mathrm{H}-\mathrm{NMR}$ spectrum in $\mathrm{CD}_{3} \mathrm{OD} ; 250 \mathrm{MHz}$.

${ }^{\text {b }}{ }^{13} \mathrm{C}-\mathrm{NMR}$ spectrum in $\mathrm{CD}_{3} \mathrm{OD} ; 500 \mathrm{MHz}$.

Validation of the docking algorithm was done by comparing the RMSD of co-crystallized ligand (COX-1 and COX-2) as well as cleaned and restructured ligand with different spatial coordinates. The RMSD for COX-1 and COX-2 was 0.58
$\AA$ and $0.92 \AA$, respectively. Free energy binding of the brominated product, 2, was lower than 1 for both COX-1 and COX-2: $-5.72 \mathrm{kcal} / \mathrm{mol}$ and $-5.61 \mathrm{kcal} / \mathrm{mol}$, respectively. Although both compounds 1 and $\mathbf{2}$ showed more positive free binding energy than the native ligand, they had the same pattern of interaction with native ligand.

Based on a study of the interaction between a ligand (1 and 2) and the binding site of proteins (PDB code $3 \mathrm{~N} 8 \mathrm{Z}$ and $6 \mathrm{COX})$, the affinity of $\mathbf{2}$ for the binding site was predicted. The energy binding of $\mathbf{2}$ was lower than $\mathbf{1}$ and native ligand, indicating that $\mathbf{2}$ has a higher affinity for these active sites than $\mathbf{1}$ and native ligand (Table 2). Analysis of protein and ligand binding revealed that both $\mathbf{1}$ and $\mathbf{2}$ fitted into the active site and interacted with protein amino acid residues Tyr385 and Met522 in COX-1 (Figure 3A) and Tyr385, Ser530, Val523, Ala527, and Leu384 in COX-2 (Figure 3B).

It can be assumed that the substitution of bromine into $\mathbf{1}$ is able to increase the interaction of $\mathbf{1}$ with the binding sites of COX-1 and COX-2.

Table 2: In silico and in vitro properties of compounds $\mathbf{1}$ and $\mathbf{2 .}$

\begin{tabular}{|c|c|c|c|c|c|c|c|}
\hline \multirow{2}{*}{ Compound } & \multicolumn{3}{|c|}{ COX-1 } & \multicolumn{3}{|c|}{ COX-2 } & \multirow[t]{2}{*}{$\mathbf{S I}^{\mathbf{b}}$} \\
\hline & $\mathrm{IC}_{50}(\mu \mathrm{M})^{\mathrm{a}}$ & $\mathbf{K i}$ & FEB & $\mathrm{IC}_{50}(\mu \mathrm{M})^{\mathrm{a}}$ & $\mathbf{K i}$ & FEB & \\
\hline 1 & 480.7018 & 252.80 & -4.90 & 52.2013 & 250.28 & -4.90 & 9.2086 \\
\hline 2 & 124.4631 & 63.63 & -5.72 & 714.7368 & 77.41 & -5.61 & 0.1741 \\
\hline Native ligand & - & 251.93 & -9.00 & - & 26.49 & -10.34 & - \\
\hline
\end{tabular}

${ }^{a}$ The result $\left(\mathrm{IC}_{50}, \mu \mathrm{M}\right)$ is the mean of two determinations acquired using the COX Screening Assay Kit, the in vitro test compound concentration required to produce $50 \%$ inhibition of enzymatic activity.

${ }^{\mathrm{b}}$ In vitro COX-2 selectivity index $\left(\mathrm{COX}-1 \mathrm{IC}_{50} / \mathrm{COX}-2 \mathrm{IC}_{50}\right)$. 


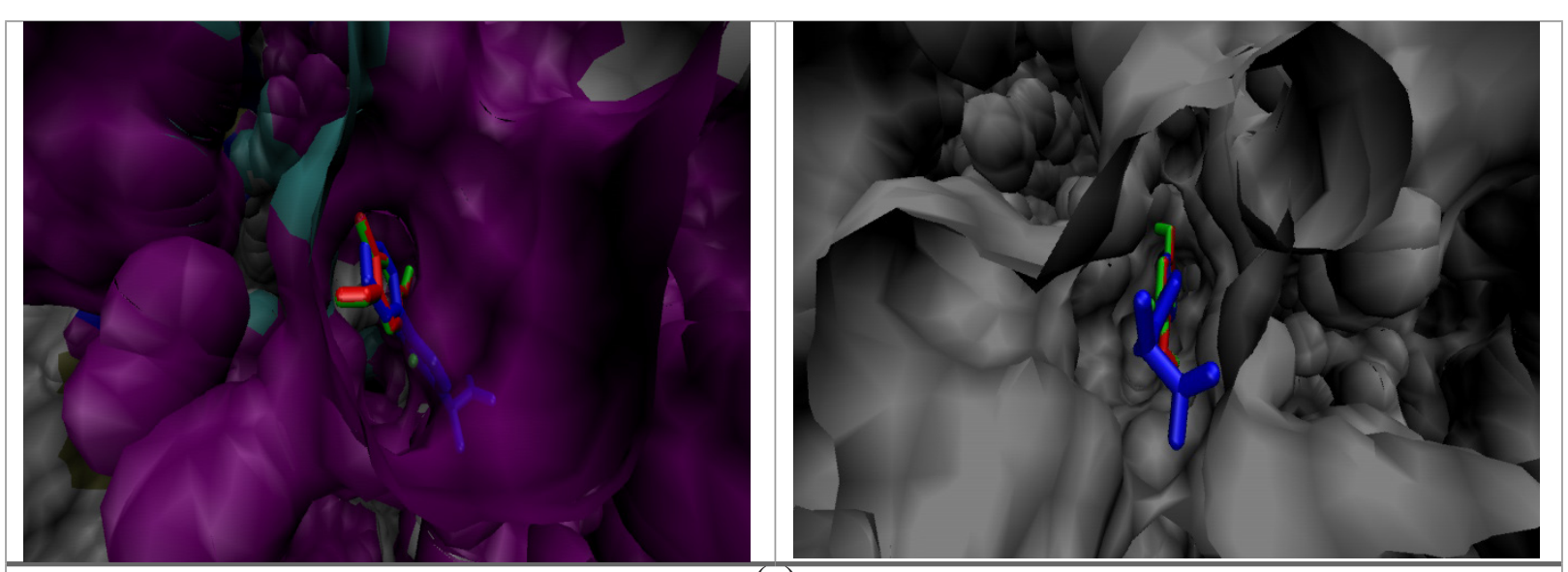

(a)
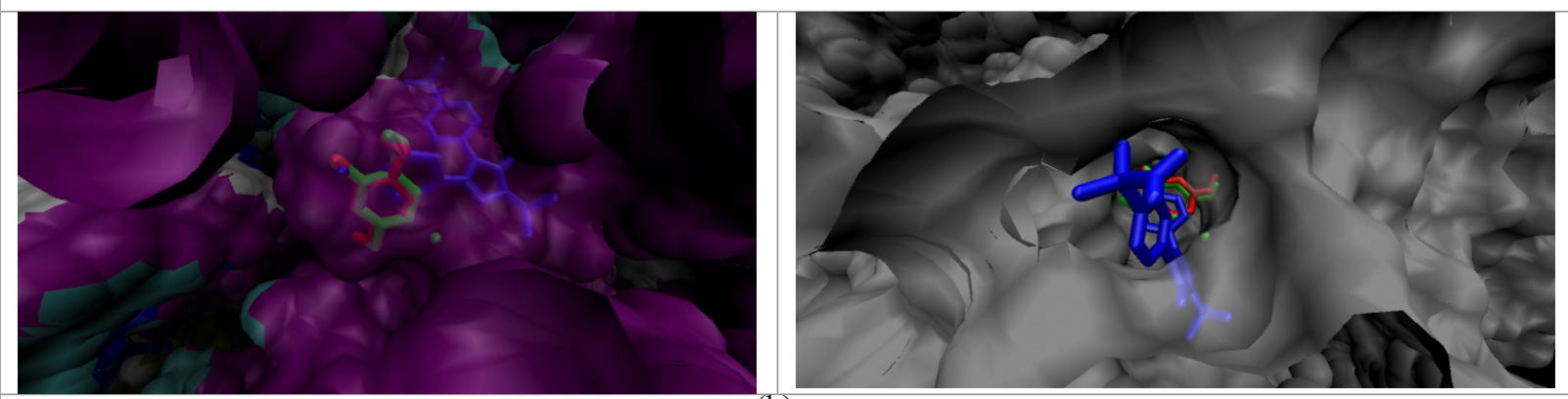

(b)

Fig. 3: (a) Orientation of compounds 1, 2, and native ligand (shown as red, green, and blue, respectively) in the COX-1 active site; (b) Orientation of compounds 1, 2, and native ligand (shown as red, green, and blue, respectively) in the COX-2 active site.

\section{CONCLUSIONS}

It is concluded that structural modification of methyl hydroquinone via substitution of bromine using NBS and AIBN in chloroform as a solvent in yield of $79.2 \%$. Bromo substitution in methyl hydroquinone plays an important role in its antiinflammatory activity.

\section{ACKNOWLEDGMENT}

This project was supported by Postdoctoral Research Grant of the Ministries of Research, Technology, and Higher Education Republic of Indonesia 2017.

\section{REFERENCES}

Amat M, Hadida S, Sathyanarayana S, Bosc J. Regioselective synthesis of 3-substituted indoles. Organic Syntheses. 1998; Collective Volume 9:417.

Buer JK. Origins and impact of the term 'NSAID'. Inflammopharmacology. 2014; 22(5):263-267. doi: 10.1007/s10787-014-0211-2.

Djerassi C. Brominations with N-bromosuccinimide and related compounds. The Wohl-Ziegler Reaction. Chem. Rev. 1948; 43(2):271-317.

García-Caballero M, Marí-Beffa M, Cañedo L, Medina MA, Quesada AR. Toluquinol, a marine fungus metabolite, is a new angiosuppresor that interferes with the Akt pathway. Biochem. Pharmacol. 2013; 85(12):1727-1740.

Gilow HW, Burton DE. Bromination and chlorination of pyrrole and some reactive 1-substituted pyrroles. J. Org. Chem. 1981; 46(11):2221. doi: $10.1021 /$ jo00324a005.

Haufe G, Alvernhe G, Laurent A, Ernet T, Goj O, Kröger S, Sattler A. Bromofluorination of alkenes. Org. Synth. 2004, 10:128.

March J. Advanced Organic Chemistry: Reactions, Mechanisms, and Structure, 3rd ed.; Wiley: New York, 1985.

Mitchell RH, Lai YH, Williams RV. N-Bromosuccinimide- dimethylformamide: a mild, selective nuclear monobromination reagent for reactive aromatic compound. J. Org. Chem. 1979; 44(25):4733. doi: 10.1021/jo00393a066.

Morris GM, Lim-Wilby M. Molecular docking, methods in molecular biology. In: Molecular Modeling of Proteins; Kukol A Ed.; Humana Press: Totowa, New Jersey, 2008; 265-382.

Morris GM, Huey R, Lindstrom W, Sanner MF, Belew RK, Goodsell DS, Olson AJ. Autodock4 and AutoDockTools4: automated docking with selective receptor flexibility. J. Comput. Chem. 2009; 16:2785-2791.

Nursamsiar N, Musfiroh I, Ibrahim S, Muchtaridi M, Tjahjono DH. Interaction study of curculigoside a and its aglycone as cyclooxygenase inhibitors using computational modelling. Int. J. Pharm. Pharm. Sci. 2013; 5(Suppl. 4):702-705.

Page CP, Curtis MJ, Sutter M, Walker M, Hoffman B. Farmacología Integrada (in Spanish). Elsevier España: Madrid, Spain, 1998. ISBN 84-8174-340-2.

Trott O, Olson AJ. AutoDock Vina: improving the speed and accuracy of docking with a new scoring function, efficient optimization and multithreading. Journal of Computational Chemistry. 2010; 31(2):455-461. doi: $10.1002 /$ jcc. 21334 .

Wolfe MM, Lichtenstein DR, Singh G. Gastrointestinal toxicity of nonsteroidal antiinflammatory drugs. N. Engl. J. Med. 1999; 340:18881899.

How to cite this article:

Nursamsiar, Asnawi A, Kartasasmita RE, Ibrahim S, Tjahjono DH. Synthesis, Biological Evaluation, and Docking Analysis of Methyl Hydroquinone and Bromo Methyl Hydroquinone as Potent Cyclooxygenase (COX-1 and COX-2) Inhibitors. J App Pharm Sci, 2018; 8(07): 016-020. 